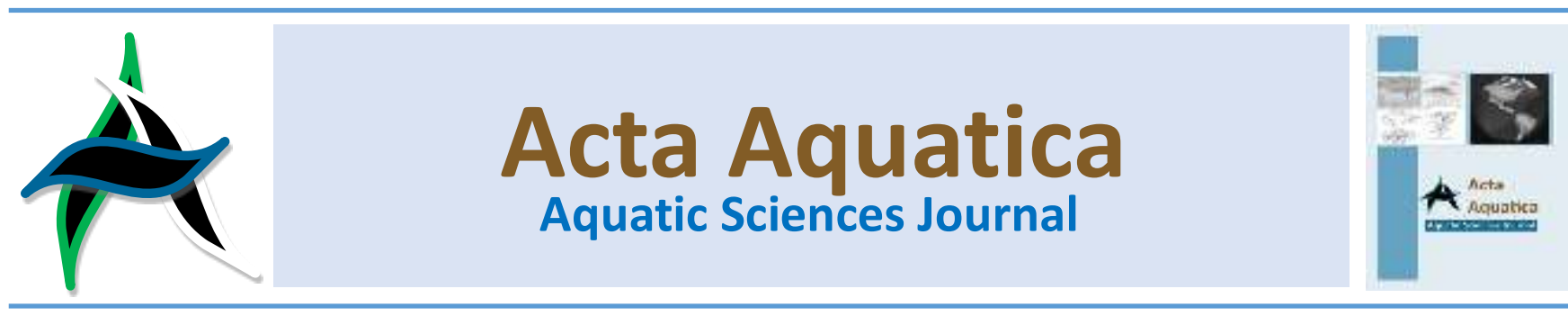

\title{
Aplikasi maserat buah mangrove Avicennia marina sebagai pengawet alami ikan nila segar
}

\section{Maserate application of Avicennia marina's fruit as natural preservative agent for tilapia}

\author{
Ahmad Pariansyah ${ }^{\text {a }}$, Nurlaila Ervina Herliany ${ }^{\text {a, }}{ }^{*}$ dan Bertoka FSP Negara ${ }^{\text {a }}$ \\ a Program Studi IImu Kelautan, Universitas Bengkulu, Bengkulu, Indonesia
}

\begin{abstract}
Abstrak
Proses pengawetan ikan merupakan salah satu bagian penting dari mata rantai industri perikanan, dimana kesegaran ikan dipertahankan selama mungkin dengan cara menghambat penyebab kemunduran mutu. Penelitian ini bertujuan untuk memperoleh maserat kasar dari buah mangrove Avicennia marina yang berpotensi sebagai bahan pengawet alami ikan segar. Penelitian ini dibagi menjadi tiga tahap, yaitu tahap persiapan, maserasi dan aplikasi. Penelitian ini menggunakan Rancangan Acak Lengkap (RAL) Faktorial yang terdiri dari dua faktor. Faktor pertama adalah bentuk esktrak yang digunakan, yaitu maserat buah mangrove dan maserat serbuk buah mangrove. Faktor kedua adalah lama penyimpanan, yaitu 0, 4, 8, dan 12 hari. Masing-masing perlakuan diulang sebanyak dua kali. Data yang diperoleh berupa hasil uji fitokimia buah mangrove, kandungan protein ikan dan nilai organoleptik ikan nila selama penyimpanan. Data protein dan organoleptik dianalisis dengan ANOVA pada tingkat kepercayaan $95 \%$, apabila ada beda nyata maka dilanjutkan dengan uji lanjut Duncan. Hasil penelitian menunjukkan bahwa buah mangrove Avicennia marina mengandung senyawa fitokimia berupa alkaloid, flavonoid, terpenoid, saponin dan tanin. Berdasarkan analisis ragam interaksi antara bentuk maserat dan lama penyimpanan tidak memberikan pengaruh nyata terhadap kadar protein ikan nila. Secara keseluruhan, nilai organoleptik ikan nila dipengaruhi oleh interaksi antara bentuk maserat dan lama penyimpanan, dimana maserat serbuk memiliki nilai organoleptik lebih tinggi dibandingkan maserat utuh selama penyimpanan.
\end{abstract}

Kata kunci: Avicennia marina; kemunduran mutu ikan; maserat; pengawet; penyimpanan

\begin{abstract}
The fish preservation process are an important partin the fishery industry, Fish freshness was maintained as long as possible by inhibiting the bacteria activity. The aim of this study was to utilized the maserate of fruit of Avicennia marina as a natural preservative agent. There are three parts in this research that are preparation, maceration and application. The factorial completely randomized design was used in this research, including two factors. First factor was the form of maserate (powder and dried mangrove fruit), and second factor was time storage $(0,4,8$, and 12 days), with every each treatment was repeated twice. Phytochemical of mangrove fruit, fish protein content and organoleptic value were test in this research. ANOVA (95\%) was used to analyzed the organoleptic and protein data. The results showed that mangrove fruit of Avicennia marina contains phytochemical compounds that are alakaloid, flavonoids, terpenoids, saponins and tannins. Based on analysis, interaction between maserate form and storage time were not have significant effect to protein content. Overall, the organoleptic value was influenced by the interaction between the maserate form and the time storage. The powder maserate has higher organoleptic value than the dried mangrove fruit during storage.
\end{abstract}

Keywords: Avicennia marina; fish deterioriation; maserate; preservative agent; storage

\section{Pendahuluan}

Proses pengawetan ikan merupakan salah satu bagian penting dari mata rantai industri perikanan, dimana pengawetan \footnotetext{
bertujuan mempertahankan kesegaran ikan selama mungkin dengan cara menghambat penyebab kemunduran mutu. Keamanan produk perikanan merupakan suatu hal yang perlu diperhatikan dalam pembangunan sektor perikanan terutama untuk konsumsi. Dalam teknologi pengolahan pangan, terdapat

* Korespondensi: Program Studi Ilmu Kelautan, Universitas Bengkulu. Jl. W.R Supratman Kandang Limun Bengkulu, Provinsi Bengkulu, 38371, Indonesia.

Tel: +62.736 .21290 Fax: +62.736 .21290$

e-mail:vivien.unib@gmail.com

doi: https://doi.org/10.29103/aa.v5i1.454
} 
berbagai usaha untuk menjaga daya simpan hasil perikanan segar, sehingga muncul bahan-bahan pengawet yang bertujuan untuk memperpanjang masa simpan. Namun dalam praktiknya, masih banyak terjadi penyimpangan penggunaan bahan pengawet yang berbahaya bagi kesehatan dan sudah dilarang, khususnya formalin (Girsang et al., 2014).

Salah satu usaha yang dapat dilakukan untuk mengatasi hal ini adalah mencari potensi dari sumber alami seperti mangrove yang mempunyai banyak sekali manfaat yang bersinggungan langsung dengan kehidupan manusia. Berdasarkan penelitian yang dilakukan oleh Sipayung et al. (2015) buah mangrove Avicennia marina memiliki aktivitas antioksidan yang tergolong tinggi yang bisa digunakan sebagai bahan pengawet. Hasil uji kandungan metabolit sekunder pada buah mangrove Avicennia marina terdapat senyawa bioaktif yaitu tanin, flavonoid dan saponin (Wibowo et al., 2009).

Masyarakat pesisir di berbagai tempat di Indonesia secara tradisional telah memanfaatkan Avicennia marina untuk pakan ternak (daun), sayuran dan makanan (biji / buah), obatobatan (getah untuk antifertilitas / mencegah kehamilan, salep dari biji untuk obat penyakit cacar / penyembuh luka), dan abu kayu untuk sabun cuci. Mangrove Avicennia marina perlu diteliti dalam hal potensinya untuk pangan, pakan dan obat-obatan, karena penggunaan untuk hal-hal tersebut perlu diuji secara ilmiah guna menjamin keamanannya sebagai pangan dan obat sekaligus peningkatan mutunya. Seiring dengan perkembangan ilmu dan teknologi, beberapa pakar giat melakukan penelitian tentang mangrove (Oktavianus, 2013).

Penelitian pada mangrove Avicennia marina pernah dilakukan oleh Iswadi et al. (2015) mengenai manfaat dari ekstrak daun Avicennia marina sebagai antibakteri dan pengawet alami ikan tongkol (Euthynus affinis) segar. Hasil penelitian menyatakan pemberian ekstrak $20 \%$ daun Avicennia marina dapat memperpanjang masa simpan ikan selama 12 jam pada suhu ruang. Sipayung et al. (2015) juga melakukan penelitian pada buah mangrove mengenai pengaruh senyawa bioaktif buah mangrove Avicennia marina terhadap tingkat oksidasi fillet ikan nila merah (O. niloticus) selama penyimpanan dingin. Penelitian menyatakan buah mangrove Avicennia marina dapat digunakan sebagai antioksidan pada fillet ikan nila merah (O. niloticus) yang disimpan dingin.

Penelitian tentang pemanfaatan maserat buah mangrove Avicennia marina sebagai bahan pengawet alami ikan segar belum dilakukan, sehingga perlu dilakukan penelitian lebih lanjut untuk mengetahui manfaat maserat buah mangrove Avicennia marina sebagai bahan pengawet alami ikan segar. Hasil dari penelitian ini diharapkan dapat dijadikan sebagai bahan informasi mengenai pemanfaatan buah mangrove Avicennia marina sebagai sumber bahan alami pengawet ikan.

\section{Bahan dan metode}

\subsection{Tahapan penelitian}

Penelitian ini dibagi menjadi tiga tahap, yaitu tahap persiapan, maserasi dan aplikasi. Tahap persiapan dilakukan untuk memperoleh sediaan kering buah mangrove yang akan digunakan pada tahap selanjutnya. Tahap maserasi dilakukan untuk memperoleh maserat buah mangrove dari tahap pertama. Tahap terakhir yaitu aplikasi dilakukan untuk memperoleh maserat yang dapat memperpanjang daya simpan ikan.

\subsubsection{Tahap persiapan}

Buah mangrove segar, dicuci menggunakan aquades kemudian dikupas dan dipotong dengan ketebalan sekitar 0,25 $\mathrm{cm}$. Potongan buah mangrove kemudian dikeringkan menggunakan oven listrik selama 10 jam pada suhu yang digunakan $70{ }^{\circ} \mathrm{C}$ (Sulistyawati et al., 2012). Sediaan kering buah mangrove yang diperoleh, disimpan dalam wadah kering untuk digunakan pada tahap maserasi. Sebagian sediaan kering dibuat menjadi bentuk serbuk menggunakan blender.

\subsubsection{Tahap maserasi}

Maserasi buah mangrove dilakukan dengan 2 perlakuan:

A. Maserasi buah mangrove Avicennia marina, yaitu dengan melakukan perendaman sediaan buah mangrove kering di dalam akuades selama 24 jam pada suhu kamar. Setelah perendaman selesai, air hasil rendaman diambil untuk diaplikasikan sebagai pengawet ikan.

B. Maserasi serbuk buah mangrove Avicennia marina, yaitu dengan merendam serbuk buah mangrove di dalam air selama 24 jam pada suhu ruang. Setelah 24 jam air maserat serbuk buah mangrove diaplikasikan untuk mengawetkan ikan.

\subsubsection{Tahap aplikasi}

Sebelum aplikasi maserat buah mangrove dilakukan, terlebih dahulu disiapkan sampel ikan nila yang akan digunakan. Ikan nila yang digunakan berukuran 120-160 gram, diperoleh dalam keadaan hidup dari tempat budidaya ikan. Ikan kemudian dibawa ke Laboratorium Perikanan untuk dimatikan dan dibersihkan. Ikan dibuang isi perutnya dan dicuci bersih, sedangkan bagian insang tidak dibuang. Maserat buah mangrove yang didapatkan pada tahap sebelumnya diaplikasikan pada ikan nila dengan cara perendaman selama 30 menit. Ikan nila yang telah direndam dalam maserat mangrove kemudian disimpan di dalam plastik dan diberi label. Selanjutnya ikan disimpan di lemari pendingin pada suhu $\pm 7 \mathrm{C}^{\circ}$ selama 4 , 8, dan 12 hari. Untuk melihat kemunduran mutunya, maka dilakukan uji protein dan organoleptik pada $0,4,8$, dan 12 hari penyimpanan.

\subsection{Variable penelitian}

\subsubsection{Uji Fitokimia}

Uji Fitokimia dilakukan untuk mengetahui senyawasenyawa apa saja yang terkandung di dalam sediaan kering buah mangrove Avicennia marina yang berpotensi untuk digunakan sebagai bahan pengawet alami ikan segar. Uji fitokimia dilakukan di Laboratorium Perikanan Universitas Bengkulu. Uji fitokimia yang dilakukan adalah uji alkaloid (Prihanto et al., 2011), uji terpenoid (Prihanto et al., 2011), uji saponin (Astuti, 2010), uji flavonoid (Astuti, 2010) dan uji tanin (Zohra et al., 2012).

\subsubsection{Uji Protein}

Uji protein dilakukan untuk mengetahui kandungan protein pada suatu bahan. Tahapan yang dilakukan dalam analisis protein terdiri dari tiga tahap, yaitu destruksi, destilasi, dan titrasi. Pengujian protein dilakukan pada daging ikan nila menggunakan metode Mikro Kjehdahl (Sudarmadji, 2003). Kandungan protein dihitung menggunakan rumus: 
Kadar $N(\% w b)=\{($ vol titrasi bahan - vol titrasi blanko $) \times \mathrm{N} \mathrm{HCl}$ x 14,007 x 100\%\}/ berat sampel (mg)

Kadar Protein $(\% w b)=$ Kadar $N \times F$

Keterangan: $\mathrm{F}=$ Faktor konversi protein $(6,25)$

$$
\text { Kadar Protein }(\% d b)=\text { kadar protein }(\% w b) /(1-k a d a r \text { air })
$$

\subsubsection{Uji organoleptic}

Uji organoleptik dilakukan dengan uji skoring untuk mengetahui perubahan fisik yang terjadi pada ikan nila selama penyimpanan. Uji organoleptik dilaksanakan berdasarkan SNI 012346-2006, yaitu penilaian organoleptik untuk ikan segar meliputi spesifikasi mutu mata, insang, lendir, bau, tekstur, dan daging (warna dan kenampakan). Uji organoleptik dilakukan menggunakan 30 orang panelis semi terlatih.

\subsection{Analisis statistik}

Percobaan aplikasi maserat buah mangrove untuk mengawetkan ikan menggunakan Rancangan Acak Lengkap (RAL) Faktorial dengan dua faktor. Faktor pertama adalah bentuk maserat yang digunakan, yaitu maserat buah mangrove Avicennia marina dan maserat serbuk buah Avicennia marina. Faktor kedua adalah lama penyimpanan yaitu 0, 4, 8, dan 12 hari. Masing-masing perlakuan diulang sebanyak 2 kali. Data kandungan protein dan organoleptik yang didapatkan dianalisis dengan menggunakan Rancangan Acak Lengkap (RAL) Faktorial pada tingkat kepercayaan 95\%. Apabila terdapat perbedaan, maka dilanjutkan dengan uji lanjut Duncan (DMRT) untuk melihat perlakuan mana yang berbeda.

\section{Hasil dan pembahasan}

\subsection{Hasil}

\subsubsection{Kandungan fitokimia buah mangrove}

Hasil analisis fitokimia menunjukan bahwa sampel buah mangrove Avicennia marina kering mengandung bahan bioaktif berupa alkaloid, terpenoid, saponin, flavonoid dan tanin. Hasil analisis fitokimia disajikan pada Tabel 1.

Tabel 1

Hasil analisis fitokimia sampel buah mangrove Avicennia marina.

\begin{tabular}{|c|c|c|}
\hline Parameter & Hasil Uji & Keterangan \\
\hline Alkaloid & $(+)$ & Terbentuk warna Orange \\
\hline Terpenoid & $(+)$ & $\begin{array}{l}\text { Terbentuk lapisan warna merah } \\
\text { kecoklatan }\end{array}$ \\
\hline Saponin & $(+)$ & Terbentuk busa yang stabil selama menit \\
\hline Flavonoid & $(+)$ & Terbentuk warna merah magenta \\
\hline Tanin & $(+)$ & $\begin{array}{l}\text { Terbentuk warna hijau hingga biru } \\
\text { kehijauan }\end{array}$ \\
\hline
\end{tabular}

Keterangan: + Terdeteksi

\subsubsection{Kadar protein}

Hasil penelitian menunjukkan bahwa selama masa penyimpanan dingin, kadar proteinikan nila mengalami penurunan (Gambar 1). Berdasarkan Gambar 1, kadar protein ikan nila yang direndam dalam maserat buah mangrove berkisar antara $89,50 \%$ sampai $71,55 \%$; sedangkan kadar protein ikan nila yang direndam dalam maserat serbuk buah mangrove berkisar antara 89,50 \% sampai 70,16\%. Hasil analisis sidik ragam (ANOVA) menunjukkan bahwa interaksi antara bentuk maserat dan lama penyimpanan tidak memberikan pengaruh nyata terhadap kadar protein ikan $(p>0,05)$. Perlakuan bentuk maserat juga tidak memberikan pengaruh nyata terhadap kadar protein $(p>0,05)$ tetapi lama penyimpanan memberikan pengaruh terhadap kadar protein ikan nila $(p<0,05)$. Berdasarkan uji Duncan, semakin lama penyimpanan maka kadar protein ikan nila juga semakin rendah.

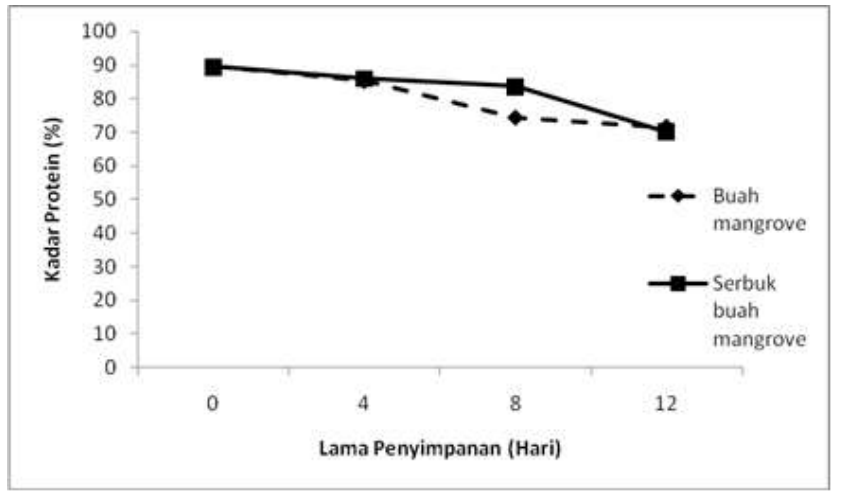

Gambar 1. Kadar protein ikan nila selama penyimpanan dingin.

\subsubsection{Nilai organoleptik}

Mata

Mata merupakan salah satu bagian tubuh ikan yang dijadikan sebagai parameter tingkat kesegaran ikan. Pada ikan segar, bola mata ikan terlihat cembung dan cerah. Sedangkan pada ikan busuk, bola mata terlihat cekung dan lebih keruh (Junianto, 2003). Nilai organoleptik mata ikan nila yang direndam dalam maserat buah mangrove berkisar antara 8,93 (cerah, bola mata menonjol, kornea jernih) sampai 6,13 (bola mata agak cekung, pupil keabu-abuan, kornea agak keruh), sedangkan nilai organoleptik mata ikan nila yang direndam dalam maserat serbuk buah mangrove berkisar antara 8,90 (cerah, bola mata menonjol, kornea jernih) sampai 6,43 (bola mata agak cekung, pupil keabu-abuan, kornea agak keruh) (Gambar 2).

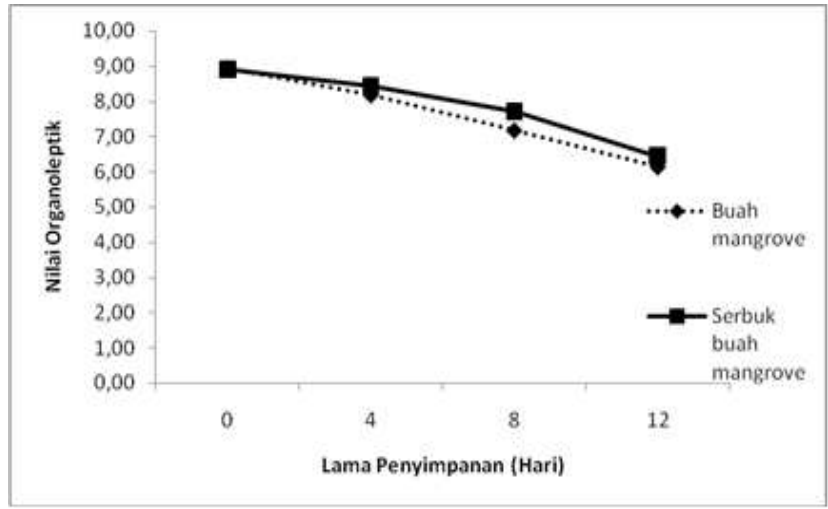

Gambar 2. Nilai organoleptik mata ikan nila selama penyimpanan dingin.

Berdasarkan analisis sidik ragam, nilai organoleptik mata selama penyimpanan dingin dipengaruhi oleh interaksi antara bentuk esktrak buah mangrove dan lama penyimpanan ( $p<$ 0,05). Hasil uji Duncan menunjukkan bahwa ikan nila yang direndam dalam maserat serbuk buah mangrove memiliki nilai organoleptik mata yang lebih tinggi selama penyimpanan dibandingkan dengan ikan nila yang direndam dengan maserat buah mangrove; dan nilai organoleptik mata mengalami penurunan seiring dengan lamanya penyimpanan. Nilai organoleptik mata yang masih dapat diterima oleh konsumen adalah 7, dengan kondisi mata agak cerah, bola mata rata, pupi 
agak keabu-abuan dan kornea agak keruh. Berdasarkan hal tersebut, nilai organoleptik mata ikan nila yang direndam dalam maserat buah mangrove dan serbuk buah mangrove dapat diterima konsumen hingga hari ke-8 penyimpanan.

Insang

Insang merupakan salah satu tempat hidup bakteri yang dapat menyebabkan kerusakan pada daging ikan. Oleh karena itu insang dapat dijadikan salah satu parameter kesegaran ikan (Irawan, 1995). Hasil penelitian menunjukkan bahwa selama masa penyimpanan dingin, nilai organoleptik insang ikan nila mengalami penurunan (Gambar 3). Berdasarkan Gambar 3, nilai organoleptik insang ikan nila yang direndam dalam maserat buah mangrove berkisar antara 9,00 (warna merah cemerlang tanpa lendir) sampai 5,53 (merah agak kusam, sedikit lendir) ; sedangkan yang direndam dalam maserat serbuk mangrove nilainya berkisar antara 9,00 (warna merah cemerlang tanpa lendir) sampai 5,63 (merah agak kusam, sedikit lendir).

Berdasarkan analisis sidik ragam, nilai organoleptik insang selama penyimpanan dingin tidak dipengaruhi oleh interaksi antara bentuk esktrak buah mangrove dan lama penyimpanan $(p>0,05)$, tetapi dipengaruhi oleh bentuk maserat dan lama penyimpanan $(p<0,05)$. Hasil uji Duncan menunjukkan bahwa ikan nila yang direndam dalam maserat serbuk buah mangrove memiliki nilai organoleptik insang yang lebih tinggi. Berdasarkan nilai organoleptik insang yang masih dapat diterima konsumen, yaitu 7 (warna merah agak kusam, tanpa lendir), maka ikan nila yang disimpan dingin masih dapat diterima oleh konsumen hingga hari ke-8 penyimpanan (untuk nila yang direndam dalam maserat serbuk buah) dan hari ke-4 penyimpanan (untuk nila yang direndam dalam maserat buah).

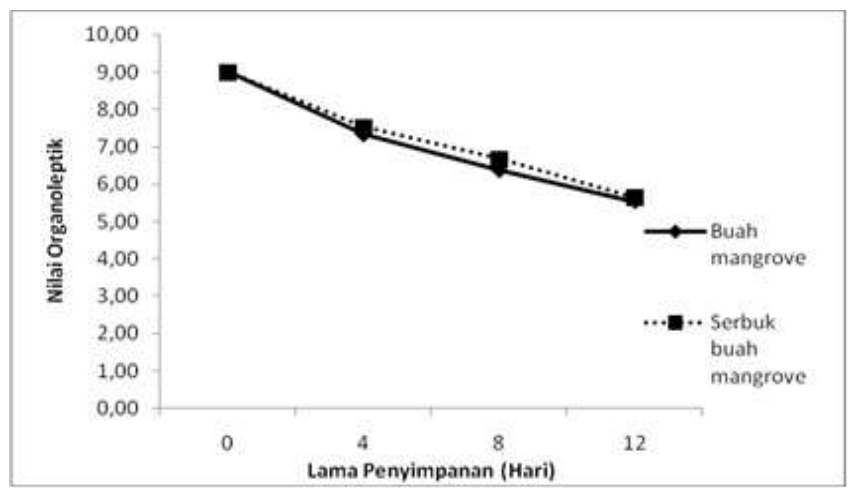

Gambar 3. Nilai organoleptik insang ikan nila selama penyimpanan dingin.

\section{Lendir permukaan badan}

Berdasarkan hasil penelitian, nilai organolepik lendir ikan nila yang direndam dalam maserat buah mangrove berkisar antara 9,00 (lapisan lendir jernih, transparan, mengkilap cerah) sampai 5,80 (lapisan lendir mulai keruh, warna putih agak kusam, kurang transparan); sedangkan nilai organoleptik lendir ikan nila yang direndam dalam maserat serbuk buah mangrove berkisar antara 9,00 (lapisan lendir jernih, transparan, mengkilap cerah) sampai 5,77 (lapisan lendir mulai keruh, warna putih agak kusam, kurang transparan) (Gambar 4). Hasil analisis sidik ragam (ANOVA) menunjukkan bahwa interaksi antara bentuk maserat dan lama penyimpanan tidak memberikan pengaruh nyata terhadap nilai organoleptik lendir ikan ( $p>0,05)$; tetapi lama penyimpanan memeberikan pengaruh terhadap nilai organoleptik lendir ikan $(p<0,05)$. Hasil uji Duncan menunjukkan bahwa semakin lama penyimpanan, maka nilai organoleptik lendir ikan juga semakin menurun. Berdasarkan nilai organoleptik lendir yang masih dapat diterima konsumen, yaitu 7 (lapisan lendir mulai agak keruh, warna agak kusam dan kurang transparan), maka ikan nila yang disimpan dingin masih dapat diterima oleh konsumen hingga hari ke-8 penyimpanan.

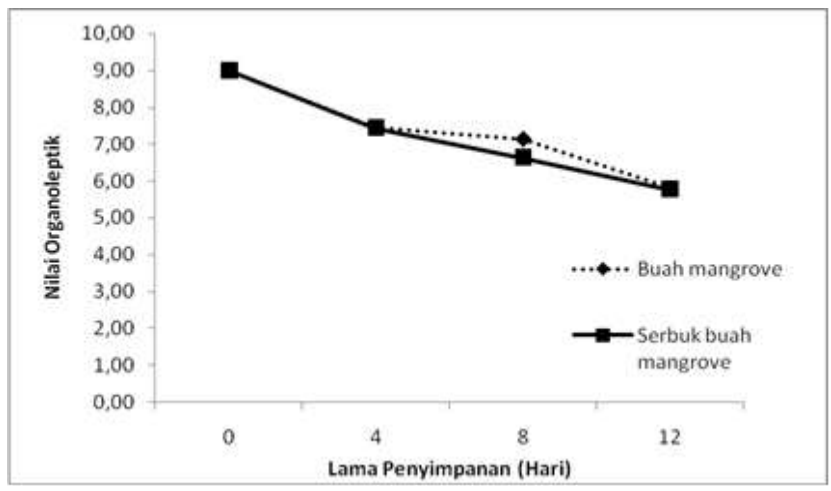

Gambar 4. Nilai organoleptik lendir permukaan badan ikan nila selama penyimpanan dingin

Daging

Daging ikan nila yang direndam dalam maserat buah mangrove memiliki nilai organoleptik berkisar antara 9,00 sampai 5,93; sedangkan nilai organoleptik daging ikan nila yang direndam dalam maserat serbuk buah mangrove berkisar antara 9,00 sampai 6,00 (Gambar 5). Daging ikan nila mengalami perubahan dari kondisi sayatan daging sangat cemerlang, spesifik jenis, tidak ada pemerahan sepanjang tulang belakang dan dinding perut pada awal penyimpanan menjadi sayatan daging mulai pudar, banyak pemerahan sepanjang tulang belakang, dan dinding perut agak lunak pada akhir penyimpanan.

Hasil analisis sidik ragam (ANOVA) menunjukkan bahwa interaksi antara bentuk maserat dan lama penyimpanan tidak memberikan pengaruh nyata terhadap nilai organoleptik daging ikan ( $p>0,05)$; tetapi lama penyimpanan berpengaruh terhadap nilai organoleptik daging ikan nila $(p<0,05)$. Hasil uji Duncan menunjukkan bahwa semakin lama penyimpanan, maka nilai organoleptik daging ikan nila semakin menurun. Berdasarkan nilai organoleptik daging yang masih dapat diterima konsumen, yaitu 7 (sayatan daging sedikit kurang cemerlang, spesifik jenis, tidak ada pemerahan sepanjang tulang belakang dan dinding perut), maka ikan nila yang disimpan dingin masih dapat diterima oleh konsumen hingga hari ke-8 penyimpanan.

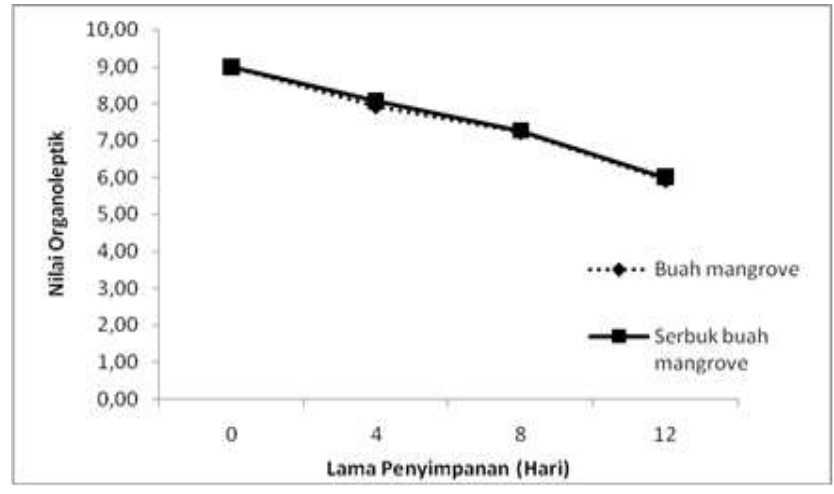

Gambar 5. Nilai organoleptik daging ikan nila selama penyimpanan dingin.

Bau

Hasil penelitian menunjukkan bahwa selama masa penyimpanan dingin, nilai organoleptik bau ikan nila mengalami penurunan (Gambar 6). Nilai organoleptik bau ikan nila yang 
direndam dalam maserat buah mangrove berkisar antara 8,97 sampai 5,20, sedangkan nilai organolepik bau ikan nila yang direndam dalam maserat serbuk buah mangrove berkisar antara 8,97 sampai 5,23. Hasil analisis sidik ragam (ANOVA) menunjukkan bahwa interaksi antara bentuk maserat dan lama penyimpanan tidak memberikan pengaruh nyata terhadap nilai organolepik bau ( $P>0,05)$; tetapi lama penyimpanan mempengaruhi nilai organoleptik bau ikan nila $(p<0,05)$. Hasil uji Duncan menunjukkan bahwa semakin lama penyimpanan maka nilai organoleptik bau akan semakin menurun. Berdasarkan nilai organoleptik bau yang masih dapat diterima konsumen, yaitu 7 (bau netral), maka ikan nila yang disimpan dingin masih dapat diterima oleh konsumen hingga hari ke-8 penyimpanan.

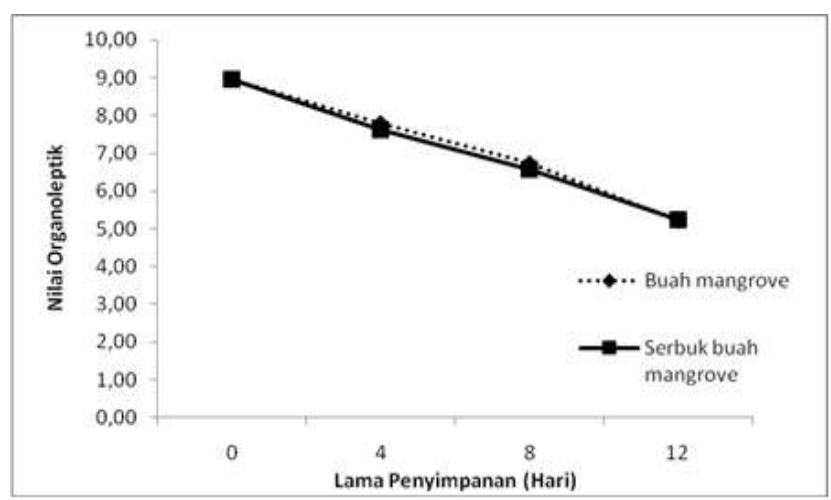

Gambar 6. Nilai organoleptik bau ikan nila selama penyimpanan dingin.

Tekstur

Hasil penelitian menunjukkan bahwa selama masa penyimpanan dingin, nilai organoleptik tekstur ikan nila mengalami penurunan (Gambar 7). Berdasarkan Gambar 7, tekstur ikan nila yang direndam dalam maserat buah mangrove berkisar antara 8,76 (padat, elastis bila ditekan dengan jari, sulit menyobek daging dari tulang belakang) sampai 4,80 (agak lunak, kurang elastis bila ditekan dengan jari, agak mudah menyobek daging dari tulang belakang). Sedangkan nilai organoleptik tekstur ikan nila yang direndam dalam maserat serbuk buah mangrove berkisar antara 8,93 (padat, elastis bila ditekan dengan jari, sulit mneyobek daging dari tulang belakang)sampai 6,00 (agak lunak, kurang elastis bila ditekan dengan jari, agak mudah menyobek daging dari tulang belakang).

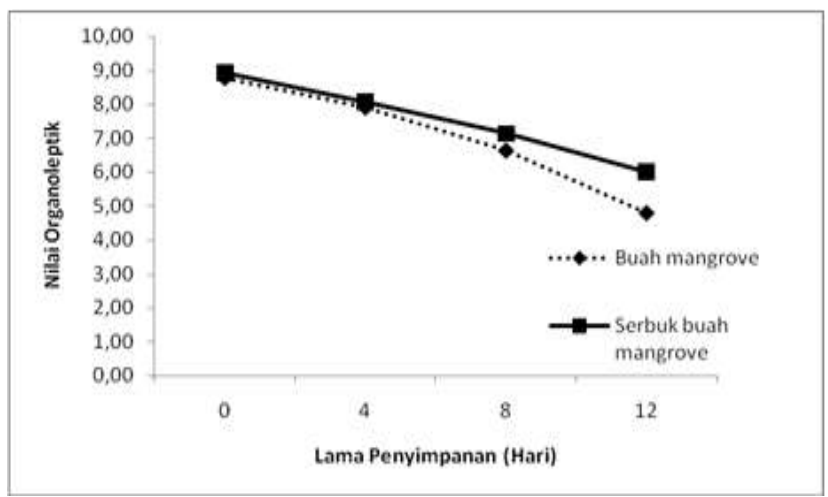

Gambar 7. Nilai organoleptik tekstur ikan nila selama penyimpanan dingin.

Hasil analisis sidik ragam (ANOVA) menunjukkan bahwa interaksi antara bentuk maserat dan lama penyimpanan memberikan pengaruh nyata terhadap nilai organolepik tekstur ikan $(p<0,05)$. Hasil uji Duncan menunjukkan bahwa pada hari penyimpanan ke-0 dan ke-4, nilai tekstur untuk nila yang direndam dengan maserat buah mangrove dan serbuk buah mangrove tidak berbeda nyata, tetapi pada penyimpanan harihari berikutnya nilai tekstur nila yang direndam dengan maserat buah mangrove lebih rendah dibanding dengan yang direndam serbuk buah mangrove. Berdasarkan batas penerimaan konsumen terhadap tekstur yaitu 7, maka ikan nila pada penelitian ini dapat diterima konsumen hingga hari ke- 8 penyimpanan.

\section{Pembahasan}

\subsection{Kandungan fitokimia}

Senyawa fitokimia pada tumbuhan mangrove memiliki fungsi untuk perlindungan tanaman terhadap berbagai faktor lingkungan. Tanaman mangrove akan beradaptasi dengan baik terhadap perubahan kondisi ekologi yang tidak memungkinkan dengan mengubah proses fisiologinya menghasilkan sintesis komponen senyawa kimia baru yang dapat melindungi mangrove dari kondisi yang ekstrim. Faktor abiotik tersebut antara lain tingginya salinitas, pasang surut perairan, suhu tinggi, oksigen rendah, rendahnya nutrisi dan kondisi angin yang kencang dimana tanaman yang lain tidak bisa tumbuh disamping itu serangga, mikroorganisme dan kegiatan manusia ikut berperan dalam peningkatan faktor stres biotik terhadap tumbuhan mangrove (Das et al., 2014).

Ditemukannya senyawa fitokimia pada penelitian ini serupa dengan hasil penelitian Mustopa et al. (2012) yang juga menemukan bahwa buah mangrove Avicennia marina mengandung senyawa aktif alkaloid, terpenoid, saponin, flavonoid dan tanin. Beberapa penelitian lain mengenai maserat mangrove juga menunjukkan bahwa maserat berbagai jenis mangrove mengandung senyawa aktif alkaloid, fenol, tanin, saponin dan flavanoid, contohnya pada Sonneratia alba (Putri et al., 2016) dan Rhizophora mucronata (Joel dan Bhimba, 2010).

Beberapa literatur menyebutkan bahwa senyawa fitokimia memiliki manfaat sebagai antibakteri yang dapat berperan sebagai penghambat pertumbuhan maupun membunuh bakteri dengan berbagai mekanisme. Mekanisme kerja alkaloid sebagai antibakteri diduga melalui penghambatan sintesis dinding sel yang akan menyebabkan lisis pada sel sehingga sel akan mati. Dinding sel yang rusak juga mengakibatkan senyawa metabolit sekunder dapat masuk lebih dalam dan merusak membran bakteri (Lamothe et al., 2009 dalam Nimah, 2012). Mekanisme terpenoid sebagai antibakteri adalah bereaksi dengan porin (protein transmembran) pada membran luar dinding sel bakteri, membentuk ikatan polimer yang kuat sehingga mengakibatkan rusaknya porin. Rusaknya porin yang merupakan pintu keluar masuknya senyawa akan mengurangi permeabilitas dinding sel bakteri yang akan mengakibatkan sel bakteri akan kekurangan nutrisi, sehingga pertumbuhan bakteri terhambat atau mati (Cowan, 1999).

Mekanisme kerja flavonoid sebagai antibakteri adalah membentuk senyawa kompleks dengan protein ekstraseluler dan terlarut sehingga dapat merusak membran sel bakteri dan diikuti dengan keluarnya senyawa intraseluler (Nuria et al., 2009 dalam Ngajow et al., 2013). Selain itu, senyawa fenol (flavonoid) dan turunannya mudah membentuk kompleks protein melalui ikatan hidrogen. Ion $\mathrm{H}^{+}$dari kompleks tersebut dapat merusak gugus fosfat membran bakteri sehingga molekul fosfolipid terurai dan menyebabkan bentuk membran tidak dapat dipertahankan (Dewi et al., 2014). Mekanisme kerja saponin sebagai antibakteri adalah menurunkan tegangan permukaan sehingga mengakibatkan naiknya permeabilitas atau kebocoran sel dan mengakibatkan senyawa intraseluler akan keluar (Robinson, 1995). Jika berlanjut, maka hal ini dapat 
menyebabkan sel bakteri lisis dan mati. Sedangkan mekanisme kerja tanin sebagai antibakteri adalah menghambat enzim reverse transkriptase dan DNA topoisomerase sehingga sel bakteri tidak dapat terbentuk (Nuria et al., 2009 dalam Ngajow et al., 2013). Menurut Cowan (1999), kemampuan aktifitas antibakteri tanin berhubungan dengan kemampuannya untuk menginaktifkan enzim dan mengganggu transport protein pada lapisan dalam sel.

\subsection{Kadar protein}

Penurunan kadar protein ikan selama penyimpanan berkaitan erat dengan kerja enzim-enzim pendegradasi protein dan bakteri-bakteri pembusuk yang merombak protein menjadi molekul yang lebih kecil. Perombakan tersebut akan diikuti dengan peningkatan jumlah bakteri pembusuk pada ikan dan munculnya bau tidak sedap (off odor) (Pradana, 2008). Menurut Adoga et al. (2010), bakteri pembusuk yang dominan terdapat pada ikan nila yang disimpan dingin antara lain Aeromonas hydrophila, E. coli dan Shigella spp.

Kadar protein ikan nila selama penelitian tidak menunjukkan penurunan yang tajam. Hal ini diduga berkaitan dengan suhu penyimpanan, perlakuan sebelum penyimpanan dan penggunaan maserat buah mangrove. Menurut Farag (2012), penyimpanan pada suhu rendah dapat memperpanjang masa simpan ikan segar karena dapat menurunkan laju aktivitas bakteri pembusuk dan mikroorganisme pathogen pada ikan. Penelitian Adoga et al. (2010) menunjukkan bahwa ikan nila yang disimpan pada suhu rendah $\left(0^{\circ} \mathrm{C}\right)$ dapat bertahan selama 15 hari sedangkan jika disimpan pada suhu ruang hanya mampu bertahan selama 12 jam. Ola dan Oladipo (2004) menambahkan bahwa penyimpanan ikan nila pada wadah berisi es dapat memperpanjang masa simpan selama 25-30 hari.

Perlakuan sebelum penyimpanan juga dapat mempengaruhi masa simpan ikan segar. Pada penelitian ini, sebelum disimpan pada suhu rendah ikan dibuang isi perutnya dan dicuci. Munandar et al. (2009) menyatakan bahwa isi perut ikan merupakan sumber utama bakteri yang menyebabkan pembusukan pada ikan. Pernyataan ini didukung oleh Junianto (2003) yang menyatakan bahwa pembuangan isi perut ikan menyebabkan salah satu sumber bakteri dan enzim di tubuh ikan tidak ada sehingga penguraian protein menjadi zat-zat yang bersifat basa lebih sedikit. Ozogul et al. (2004) menambahkan bahwa sebagian besar senyawa-senyawa yang bersifat volatil dihasilkan oleh akivitas bakteri yang berpusat pada isi perut ikan. Pembusukan pada ikan diakibatkan oleh perubahan biokimiawi dan fisikawiyang pada akhirnya menjurus pada kerusakan secara menyeluruh yaitu pembusukan. Oleh karena itu ikan nila yang dibuang isi perutnya memiliki masa simpan lebih lama dibandingkan ikan yang idak dibersihkan perutnya.

Penggunaan maserat buah mangrove pada ikan nila diduga dapat memperpanjang daya simpan karena maserat buah mangrove mengandung senyawa fitokimia yang dapat berperan sebagai antibakteri atau anti mikrobia. Iswadi et al. (2015) menyatakan bahwa antibakteri pada maserat mangrove dikarenakan maserat mangrove mengandung senyawa seperti saponin, flavonoid dan tannin yang mampu mengendalikan perkembangan bakteri dengan cara merusak membrane sitoplasma dan membunuh sel epidermis. Pada penelitian ini, lama penyimpanan mempengaruhi kadar protein ikan selama penelitian. Hal ini sesuai dengan penelitian yang dilakukan oleh Hidayati et al. (2017) yang menyatakan bahwa lama waktu penyimpanan suhu rendah berpengaruh nyata terhadap perubahan kadar protein ikan. Pernyataan tersebut didukung oleh penelitian yang dilakukan oleh Nurhayati (2011) yang menyatakan bahwa penurunan kadar protein pada ikan di dipengaruhi oleh lama penyimpanan dan suhu yang digunakan.

\subsection{Nilai organoleptik}

Penurunan nilai organoleptik mata menunjukkan bahwa terjadi penurunan kesegaran ikan selama penyimpanan. Menurut Pianusa et al. (2015), salah satu ciri kemunduran mutu ikan adalah berubahnya kondisi mata ikan menjadi terbenam dan pudar akibat adanya aktivitas bakteri pembusuk. Aktivitas bakteri pembusuk dapat ditekan dengan penggunaan maserat buah mangrove. Menurut Pianusa et al. (2015), kandungan flavonoid dan tanin yang terdapat dalam maserat buah mangrove dapat berfungsi sebagai antibakteri untuk menekan aktivitas bakteri pembusuk sehingga kesegaran ikan dapat bertahan lebih lama. Ningsih (2016) menambahkan bahwa maserat yang berasal dari serbuk memiliki kandungan fitokimia yang lebih tinggi dibandingkan dengan maserat yang berasal dari bahan. Hal ini berkaitan dengan luas permukaan yang kontak dengan pelarut, dimana serbuk memiliki luas permukaan yang lebih besar untuk kontak dengan pelarut sehingga dimungkinkan lebih banyak senyawa-senyawa yang termaserat (Maslukhak et al., 2016; Mabiki et al., 2013; Baldosano et al., 2015).

Insang merupakan salah satu sumber bakteri pembusuk pada ikan. Selama proses pembusukan terjadi, bakteri yang terdapat pada insang jumlahnya akan berlipat ganda dan dapat berpindah menuju bagian tubuh ikan yang lain. Hal ini mengakibatkan proses kebusukan ikan menjadi semakin cepat. Oleh karena itu, salah satu cara untukmempertahankan kesegaran ikan adalah dengan membuang sumber-sumber bakteri, salah satunya adalah insang (Junianto, 2003). Perbedaan nilai organoleptik insang yang direndam maserat serbuk buah dan buah mangrove dikarenakan maserat serbuk buah memiliki kandungan fitokimia yang lebih tinggi karena berkaitan dengan luas permukaan bahan yang kontak dengan pelarut sehingga berdampak pada lebih banyaknya senyawa-senyawa yang termaserat (Maslukhak et al., 2016; Mabiki et al., 2013; Baldosano et al., 2015).

Terbentuknya lendir merupakan tanda awal terjadinya proses kemunduran mutu (fase pre-rigor). Lendir yang dikeluarkan ini sebagian besar terdiri dari glukoprotein dan musin yang merupakan media ideal bagi pertumbuhan bakteri (Junianto, 2003). Lendir-lendir yang terlepas tesebut membentuk lapisan bening yang tebal di sekeliling tubuh ikan. Pelepasan lendir dari kelenjar lendir ini merupakan reaksi alami ikan yang sedang sekarat terhadap keadaan yang tidak menyenangkan. Jumlah lendir yang terlepas dan menyelimuti tubuh dapat sangat banyak hingga mencapai 1-2,5\% dari berat tubuhnya (Murniyati dan Sunarman, 2000).

Pembentukan lendir pada ikan selama penyimpanan lebih diakibatkan karena deteriorasi lanjut oleh aktivitas bakteri pembusuk yang mengeluarkan lendir sebagai salah satu hasil metabolisme bakteri pembusuk yang meningkat secara signifikan pada akhir penyimpanan (Odoli, 2009). Berdasarkan Murniyati dan Sunarman (2000), pada proses pembusukan ikan terjadi tahap Hiperaemia yaitu lendir ikan terlepas dari kelenjarkelenjarnya didalam kulit, membentuk lapisan bening yang tebal disekeliling tubuh ikan. Selain itu, jika suhu lingkungan naik maka aktivitas bakteri menjadi lebih cepat sehingga membuat pelepasan lendir dari kelenjar menjadi tebal dan keruh.

Perendaman ikan nila pada maserat mangrove mengakibatkan lendir permukaan tubuh ikan berubah warna menjadi putih kekuningan. Menurut Malanggi (2012), hal ini berkaitan dengan kandungan tanin yang terdapat pada ekstrak buah mangrove. Senyawa tanin dapat teroksidasi jika terlalu lama terpapar udara sehingga menghasilkan warna kekuning- 
kuningan yang dapat mempengaruhi kenampakan lendir pada tubuh ikan.

Nilai organoleptik daging ikan selama penelitian mengalami penurunan, baik yang direndam maserat buah maupun serbuk buah mangrove. Hal ini mengindikasikan adanya penurunan kesegaran ikan selama penyimpanan dingin. Perubahan tekstur daging ikan menjadi lembut dan lunak disebabkan karena adanya proses autolisis yang menimbulkan perubahan pada daging, seperti daging menjadi lunak dan mudah lepas dari tulang (Gustini et al., 2014). Walaupun buah mangrove mengandung senyawa fitokimia yang mampu berperan sebagai antibakteri tetapi seiring dengan lamanya penyimpanan, jumlah bakteri pembusuk yang ada pada ikan semakin banyak dan aktivitasnya semakin meningkat sehingga pada akhir penyimpanan, daging ikan berubah teksturnya.

Bau ikan nila mengalami perubahan yaitu berbau sangat segar dan spesifik jenis pada awal penyimpanan hingga mulai tercium bau ammoniak dan bau asam pada akhir penyimpanan yang menandakan bahwa ikan telah mengalami pembusukan. Menurut Junianto (2003), faktor yang menyebabkan ikan cepat mengalami bau busuk adalah kadar glikogennya rendah sehingga rigor mortis berlangsung lebih cepat. Oyelese (2006) menyatakan bahwa aktivitas bakteri pembusuk dalam mendekomposisi lemak dan protein menghasilkan senyawa-senyawa yang tidak diinginkan seperti ammoniak, indol, dan $\mathrm{H}_{2} \mathrm{~S}$ yang menyebabkan timbulnya bau tidak sedap dan rasa yang tidak enak pada ikan.

Pemilihan tekstur oleh konsumen pada umumnya dilakukan untuk mendapat bahan makanan yang masih dalam keadaan baik sehingga layak untuk dikonsumsi. Tekstur makanan yang baik adalah yang masih segar, tidak lembek dan berlendir (Andayani et al., 2014). Tekstur pada ikan berkaitan erat dengan proses kemunduran mutu yang terjadi setelah ikan mati. Sesaat setelah ikan mati, otot-otot ikan melemas sehingga mudah dilenturkan (fase pre-rigor). Hal ini disebabkan oleh terhentinya peredaran darah yang membawa oksigen untuk metabolisme. Seiring dengan semakin lamanya waktu setelah kematian, otot ikan menjadi kaku (fase rigor mortis). Pada tahap akhir pembusukan, otot ikan kembali melemas dan hilang elastisitasnya (fase post-rigor). Hal ini disebabkan oleh aktivitas bakteri dan enzim yang tidak terkendali sehingga terjadi degradasi protein otot ikan (Pradana, 2008).

Penggunaan buah mangrove diduga dapat memperpanjang daya simpan ikan segar. Penelitian Sipayung et al. (2015) menunjukkan bahwa pada perlakuan fillet dengan penambahan buah mangrove pada suhu dingin $\pm 5^{\circ} \mathrm{C}$ bertahan hingga 8 hari, sedangkan perlakuan fillet tanpa penambahan buah mangrove pada suhu dingin $5^{\circ} \mathrm{C}$ secara organoleptik hanya bertahan sampai hari ke 4 karena pada hari ke 8 sudah tidak layak dikonsumsi. Hal ini sesuai dengan Mahatmanti (2010) yang menyatakan bahwa pada suhu $15-20^{\circ} \mathrm{C}$, ikan dapat disimpan hingga sekitar 2 hari, pada suhu $5^{\circ} \mathrm{C}$ tahan selama 5-6 hari, sedangkan pada suhu $0^{\circ} \mathrm{C}$ dapat mencapai 9-14 hari, tergantung spesies ikan. Ini menunjukkan bahwa dengan penambahan buah mangrove dapat memperpanjang umur simpan ikan hingga 2 hari yang pada dasarnya hanya dapat bertahan 5-6 hari.

\section{Kesimpulan}

Buah mangrove Avicennia marina mengandung senyawa fitokimia berupa tanin, alkaloid, terpenoid, flavonoid dan saponin. Berdasarkan analisis sidik ragam, kadar protein ikan nila tidak dipengaruhi oleh interaksi antara bentuk maserat dan lama penyimpanan tetapi hanya dipengaruhi oleh lama penyimpanan. Secara keseluruhan, nilai organoleptik ikan nila dipengaruhi oleh interaksi antara bentuk maserat dan lama penyimpanan, dimana maserat serbuk buah mangrove memiliki nilai organoleptik lebih tinggi dibandingkan buah mengrove selama penyimpanan.

\section{Bibliografi}

Adoga, I.J., Egila, J., Onojowo, F.S., 2010. Storage life of Tilapia (Oreochromis niloticus) in ice and ambient temperature. Researcher. 2 (5), 39-44.

Andayani, T., Yusuf, H., Rini, Y., 2014. Minyak atsiri daun sirih merah (Piper crocatum) sebagai pengawet alami pada ikan Teri (Steplophorus indicus). Jurnal Bioproses Komoditas Tropis 2 (2), 123-130.

Astuti, S. M., 2010. Skrining fitokimia dan uji aktifitas antibiotika maserat etanol daun, batang, bunga, dan umbi tanaman binahong (Auredera cordifolia (Ten) Steenis). Skripsi dari Universitas Malaysia Pahang, Malaysia.

Baldosano, Y.H., Beatrice, M.G.C., Chantal D.H. E., Florinda, T.B., 2015. Effect of particle size, solvent and extraction time on tannin extract from Spondias purpurea bark through soxhlet extraction. Proceedings of the DLSU Research Congress De La Salle University Vol 3, Manila, Philippines, pp 1-6.

Cowan, M., 1999. Plant Product as Antimicrobial Agent. Clinical Microbiology Rev., 12 (4), 564-582

Das, S.K., Dibyajyoti, S., Hrudayanath, T., 2014. Ethnomedicinal, antimicrobial and antidiarrhoeal studies on the mangrove plants of the genus Xylocarpus: a mini review. J. Bioanal. Biomed. (12), 1-7.

Dewi, M.K., Evie, R., Guntur, T., 2014. Aktivitas antibakteri ekstrak daun Majapahit (Crescentia cujete) terhadap pertumbuhan bakteri Ralstonia solanacearum penyebab penyakit layu. LenteraBio 3 (1), 51-57.

Farag, Y., Leopold, C.S., 2012. Development of shellac coated sustained release pellet formulations. European J. of Pharmaceutical Sci. 42, 400-405.

Girsang, D.Y., Azhari, R., Susilawati, 2014. Kasus distribusi dan penggunaan formalin dalam pengawetan komoditi ikan laut segar (studi kasus di Kota Bandar Lampung). J. Tekn. dan Industri Hasil Pertanian 19 (3), 218-228.

Gustini, Siti, K., Ari, H.Y., 2014. Kualitas ikan kembung (Rastrelliger kanagurta) setelah perendaman dalam kitosan ditinjau dari aspek mikrobiologi dan organoleptik. J. Protobiont 3 (2), 100-105.

Hidayati, F., Y.S. Darmanto, Romadhon, 2017. Pengaruh perbedaan konsentrasi ekstrak Sargassum sp. dan lama penyimpanan terhadap oksidasi lemak pada fillet ikan Patin (Pangasius sp.). J. Ilmu Lingkungan, 15 (1), 64-73.

Irawan, H.S.R., 1995. Pengawetan ikan dan hasil perikanan. CV Aneka. Solo.

Iswadi, Samingan, Ida, S., 2015. Ekstrak daun api-api (Avicennia marina) sebagai anti bakteri dan pengawet alami ikan tongkol (Euthynus affinis) segar. J. Bio. Ed. edisi 14.7 (1), 7-12. 
Joel, E.L., Bhimba, V., 2010. Isolation and characterization of secondary metabolites from the mangrove plant Rhizophora mucronata. Asian Pacific J. of Tropical Med. 602-604

Junianto, 2003. Teknik Penanganan Ikan. Penebar Swadaya. Jakarta.

Mabiki, F.P., Joseph, J.M., Robinson, H.M., Resto, D.M., 2013. Optimization of ekstraction condition and phitiochemical screening of rot ekstract of Syinadenium glaucescens Pax. Intern. J. of Chem. 5 (4), 103-112

Mahatmanti, F.W., Warlan, S., Wisnu, S., 2010. Sintesis khitosan dan pemanfaatannya sebagai antimikroba ikan segar. Skripsi dari Fakultas Matematika dan Ilmu Pengetahuan Alam Universitas Negeri Semarang, Semarang.

Malangngi, L.P., Meiske, S.S., Jessy, J.E.P., 2012. Penentuan kandungan tanin dan uji aktivitas antioksidan ekstrak biji buah alpukat (Persea americana Mill.). J. Mipa UNSRAT, 1 (1), 5-10.

Maslukhah, Y.L., Tri, D.W., Elok, W., Novita, W., Feronika, H.S., 2016. Faktor pengaruh ekstraksi cincau hitam (Mesona palustris BI) Skala Pilot Plant: Kajian Pustaka. J. Pangan dan Agroindustri 4 (1), 245-252.

Munandar, A., Nurjanah, Mala, N., 2009. Kemunduran mutu ikan nila (Oreochromis niloticus) pada penyimpanan suhu rendah dengan perlakuan cara kematian dan penyiangan. J. Teknol. Peng. Has. Perik. Ind. XII (2), 88 101.

Murniyati, A.S., Sunarman., 2000. Pendinginan, pembekuan dan pengawetan ikan. Penerbit Kanisius. Jakarta.

Mustopa, A.Z., Melki., Ika, S.K., 2012. Isolasi dan identifikasi awal senyawa inhibitor RNA helikase virus hepatitis $C$ dari ekstrak buah mangrove Avicennia marina (forsk.) Vierh. J. Peng. Has. Perik. Indonesia 15 (2), 127-135.

Nimah, S., Widodo, F.M., Agus, T., 2012. Uji bioaktivitas ekstrak teripang pasir (Holothuria scabra) Terhadap Bakteri Pseudomonas aeruginosa dan Bacillus cereaus. J. Perik. 1 (2), 1-9

Ningsih, D.R., Zusfahair, Dwi, K., 2016. Identifikasi senyawa metabolit sekunder serta uji aktivitas ekstrak daun sirsak sebagai Antibakteri. Molekul, 11 (1), 101-111

Ngajow, M., jemmy, A., Vanda, S.K., 2014. Pengaruh antibakteri ekstrak kulit batang matoa (Pometia pinnata) terhadap Bakteri Staphylococcus aurens secara In Vitro. J. Mipa Unsrat 2 (2), 128-132.

Nurhayati, T., Ella, S., Komariah, T., Ary, A., 2011. Peranan inhibitor katepsin dari ikan patin (Pangasius hypophthalmus) untuk menghambat kemunduran mutu ikan bandeng (Chanos chanos Forskal). J. Peng. Has. Perik. Indonesia, XIV (1), 49-55.

Odoli, C.O., 2009. Optimal storage conditions for fresh farmed tilapia (Oreochromis niloticus) fillets. Tesis dari Department of Food Science and Nutrition, Faculty of Science. University of Iceland, Iceland.
Oktavianus, S., 2013. Uji daya hambat ekstrak daun mangrove jenis Avicennia marina terhadap bakteri Vibrio parahaemolyticus. Skripsi dari Fakultas IImu Kelautan dan Perikanan Universitas Hasanuddin, Makassar.

Ola, J.B., Oladipo, A.E., 2004. Storage life of croaker (Pseudotholitus senegalensis) in ice and ambient temperature. African J. of Biomedical Res., África do Sul. 7 (1), 13-17.

Oyolese, A.O., 2006. Quality assesment of cold smoked hot smoked and oven dried tilapia nilotica under cold storage temperature conditions. J. of Fish. Int. 2 (4), 92-97.

Ozogul, F., Polat, A., and Ozogul, Y., 2004. The effect of modified atmosphere packaging and vacuum packaging on chemical, sensory and microbiological change of sardines (Sardina pilchardus). Food Chem. 85, 49-57.

Pianusa, A.F., Grace, S., Wonggo, D., 2015. Kajian perubahan mutu kesegaran ikan tongkol (Euthynnus affinis) yang direndam dalam ekstrak rumput laut (Eucheuma spinosum) dan ekstrak buah bakau (Sonneratia alba). J. MediaTek. Hasil Perik. 3 (2), 66-74.

Pradana, A.Y., 2008. Perananan tepung daun jambu biji (Psidium guajava) terhadap kemunduran mutu fillet ikan nila (Oreochromis sp). Skripsi dari Institut Pertanian Bogor, Bogor.

Prihanto, A. A., Firdaus, M., Nurdiani, R., 2011. Penapisan fitokimia dan antibakteri ekstrak metanol mangrove (Excoecaria agallocha) dari Muara Sunga Porong. Berk. Penel. Hayati 17, 69-72.

Putri, R.R., Rafitah, H., Indrati, K., 2016. Uji aktivitas antibakteri dan Uji fitokimia ekstrak daun mangrove Sonneratia alba. J. Aquawarman, 2 (1), 43-50

Robinson, T., 1995. Kandungan Organik Tumbuhan Tinggi. ITB. Bandung, Indonesia.

Sipayung, B.S., Widodo, F.M., Eko, N.D., 2015. Pengaruh senyawa bioaktif buah mangrove Avicennia marina terhadap tingkat oksidasi fillet ikan nila merah O.niloticus selama penyimpanan dingin. J. Peng. dan Biotek. Has. Perik. 4 (2), 115-123.

SNI 01-2346-2006. Petunjuk pengujian organoleptik dan atau sensori. Badan Standarisasi Nasional. Jakarta.

Sudarmadji, S.B. Haryono, Suhardi. 2003. Analisa bahan makanan pertanian. Liberty. Yogyakarta.

Sulistyawati, Wignyanto, Sri, K., 2012. Produksi tepung buah lindur (Bruguiera gymnorrhiza Lamk) rendah tanin dan HCN sebagai bahan pangan alternatif. J. Tekn. Pertanian, 13 (3), 187-198.

Wibowo, C., Kusmana C., Suryani A., Hartati Y., Oktadiyani, P., 2009. Pemanfaatan pohon mangrove api-api (Avicennia spp.) sebagaii bahan pangan dan obat. Prosiding Seminar Hasil-Hasil Penelitian Fakultas Kehutanan. IPB. Bogor, pp 158-166. 
Zohra, S.F., Belarbi, M., Sabri, S., Alsayadi, M.M.S., 2012. Phytochemical screening and identification of some compounds from mallow. J. Nat. Prod. Plant. Resour. 2 (4), 512-516. 